\title{
APPLICATION OF SPATIAL MODELING FOR UPLAND COTTON YIELD IN THE SEMI-ARID OF PARAÍBA STATE, BRAZIL
}

\author{
Madson T. Silva ${ }^{*}$, Antônia S. de Andrade², Edivaldo A. de O. Serrão², \\ Vicente de P. R. da Silva ${ }^{1}$, Enio P. de Souza ${ }^{1}$
}

\author{
${ }^{1 *}$ Corresponding author. Unidade Acadêmica de Ciências Atmosféricas, Universidade Federal de Campina Grande (UFCG)/ Campina \\ Grande - PB, Brasil. E-mail: madson.tavares@ufcg.edu.br | ORCID ID: https://orcid.org/0000-0003-1823-2742
}

\section{KEYWORDS}

variability, yield, spatial analysis.

\begin{abstract}
This study aimed to evaluate the spatial dependence between agrometeorological variables and upland cotton yield the microregion of Cariri Oriental, Paraíba state (Brazil), using weighted spatial modeling system. In this study, we used the historical agricultural production data from the Brazilian Institute of Geography and Statistics (IBGE), observed rainfall data from the Executive Water Management Agency of Paraíba State (AESA), and air temperature averages estimated by the Estima T software. Spatial regression models (classical - CR, autoregressive - SARM, and spatial error - SEM) were used to correlate the dependent variable (upland cotton yield) with covariates (agrometeorological variables). Fitted model parameters were estimated using the Maximum Likelihood method. Model performance was evaluated based on coefficient of determination $\left(\mathrm{R}^{2}\right)$, maximum likelihood function logarithm (AIC), and spatial residue analysis. Moreover, an exploratory spatial analysis allowed us to verify spatial autocorrelation between upland cotton yield and agrometeorological elements, using statistical tools such as Moran's index I.
\end{abstract}

\section{INTRODUCTION}

Cotton (Gossypium hirsutum L. var. latifolium Hutch) is one of the most grown crops worldwide due to the extensive use of its fiber in the textile industry. According to the United States Department of Agriculture (USDA), the global lint cotton production in the 2018/19 harvest season was estimated at about 26 million tons. In Brazil, it represents $55.7 \%$ of the raw materials and is the main natural fiber used in the textile industry (ABRAPA, 2018).

Brazil is the third largest producer (27,258.000 tons) and the second largest exporter of cotton (847,500 tons) in the world (ABRAPA, 2018). Northeast Brazil, in turn, is the second largest producer of cotton in the country and contributes by $26 \%$ to the national production. Moreover, the textile park in this region is one of the largest centers for purchase of manufactured cotton in Latin America (Oliveira et al., 2012).

The world's population is estimated to grow from two to three billion people by 2050 . Such population growth, combined with middle-class expansion, will increase food, energy, and fiber demands significantly (Foley et al., 2011).

Agricultural crop management has become gradually data-driven and data-enabled, with large and diverse amounts of potential information available from crop and soil samplings, sensors, spatial mapping, historical yield measurements, remote sensing products of soils and crops, and weather measurements (Wolfert et al., 2017).

Crop yield spatial variability is affected by multiple factors including soil, terrain, plant properties, weatherrelated factors, environmental impacts, as well as human intervention type and extent (Scudiero et al., 2013). The influence of these factors on crop water status and yield can support management decisions and help develop irrigation systems and more efficient methods to increase productivity (Masseroni et al., 2017; Rocha Júnior et al., 2019).

However, according to IPCC (2013), signatures of climate change are already evident in observations of natural and human systems, which suggests that society will face altered weather conditions in the future. Thus, cotton breeding has become a priority in Northeast Brazil to obtain

\footnotetext{
${ }^{1}$ Unidade Acadêmica de Ciências Atmosféricas, Universidade Federal de Campina Grande (UFCG)/ Campina Grande - PB, Brasil.
}

${ }^{2}$ Programa de Pós-graduação em Meteorologia, Universidade Federal de Campina Grande (UFCG)/ Campina Grande - PB, Brasil. 
productive cultivars, resistant to pests and diseases, and adapted to local edaphoclimatic conditions, as well as with special, fine, and resistant fibers of varied colors (Echer et al., 2010; Gilio et al., 2017).

Silva et al. (2012; 2020a) evaluated climate change impact on upland cotton (Gossypium hirsutum L. latifolium Hutch) in northeastern Brazil through arable-land availability for rainfed crops. Silva et al. (2012) verified climate monitoring and agricultural production in the states of Paraíba, Rio Grande do Norte, and Ceará over the last twenty years, comparing the interannual variability of agricultural production and rainfall, and obtained significant results. According to Silva et al. (2020b), several agrometeorological models have pointed out significant reductions in rainfall and increases in temperature, and hence an increasing trend of evapotranspiration in a future projection (2020-2080).

The climate and crop yield relationship widely reported in the literature is based on global estimates, as it varies with space (Lobell \& Burke, 2010). These estimates can help mitigate effects and adapt crops to climate at spatial scales, but can be misleading in site-specific programs, particularly those aimed at adapting farmers. Therefore, knowing climate impacts on crop yields at a local scale can provide useful information to policy makers.

Peeters et al. (2015) suggested a multivariate spatial clustering by the Getis-Ord Gi* statistic to characterize spatial variability. The study of Goldstein et al. (2018) stands out among the studies using machine learning to analyze multivariable effects on crop yield. In this context, studies addressing the spatial relationships of soil traits, climate, and plant conditions with crop yields in a multivariate way are still incipient, which may neglect management properties that directly influence production efficiency.

Fotheringham et al. (2015) stated that geographically weighted regression (GWR) is a statistical method for spatial modeling of heterogeneous processes and enables relating response variables with a set of independent variables. Given its greater analytical capacity and detail level, this approach has higher accuracy and efficiency of estimation (Ahmadi et al., 2018). A major component of the GWR is spatial weight, through which spatial relationships are delineated. The spatial weights are usually defined by spatial nuclear functions such as the Gaussian (Fotheringham et al., 2015), in which weights are related to the closest observations. Several studies have explored GWR models (Di Leo et al., 2016; Luo \& Peng, 2016; Zhao et al., 2018; Andrade et al., 2021, and Silva et al., 2021). Among them, many have used one or more methods using biophysical variables as independent variables to explain the spatial variability of various physical phenomena of nature.

Therefore, the present study aimed to evaluate the spatial dependence between agrometeorological variables and upland cotton yield in the microregion of Cariri Oriental, Paraíba state (Brazil), using weighted spatial modeling system.

\section{MATERIAL AND METHODS}

\section{Study area}

The study area is in the microregion of Cariri Oriental, in Paraíba state, Brazil (Figure 1), which encompasses 12 municipalities. According to the census of IBGE (2015), the microregion has an area of 4,219.150 $\mathrm{km}^{2}$, with an estimated population of 63,704 inhabitants (IBGE, 2015).

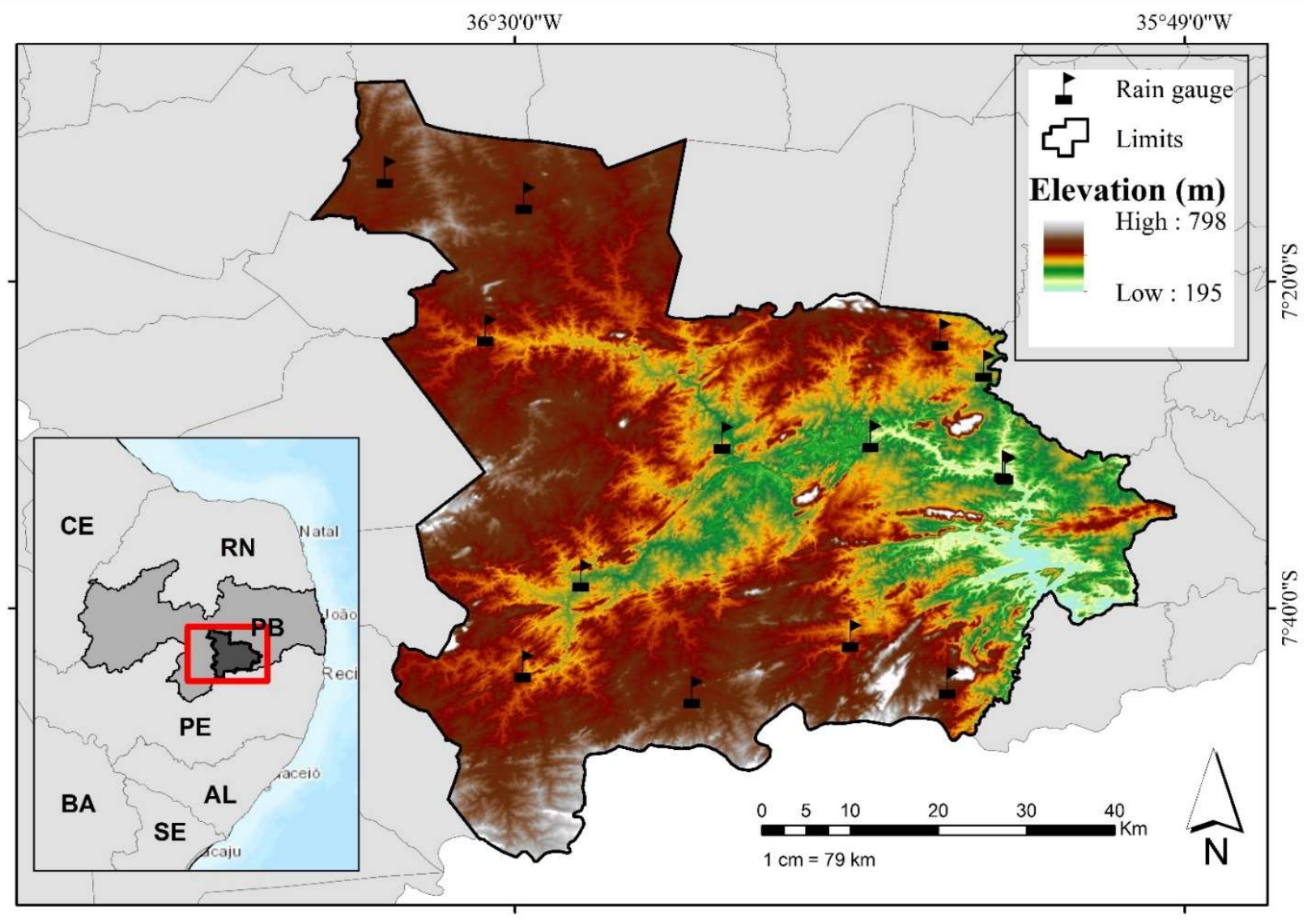

FIGURE 1. Location of the microregion of Cariri Oriental, Paraíba state, Brazil. 
The region is characterized by high temperatures (annual averages around $26{ }^{\circ} \mathrm{C}$ ), low thermal amplitudes (Nascimento \& Alves, 2008), and rain scarcity. Annual rainfall varies greatly in both time and space and has an average of about $587 \mathrm{~mm}$, with standard deviation of \pm 230 $\mathrm{mm}$ (Sena et al., 2012). According to Alvares et al. (2014), the microregion of Cariri Oriental in Paraiba state has a BSh climate type.

\section{Database}

We used rainfall data from a monthly rainfall series (2000-2017) provided by the Executive Agency for Water Management of the State of Paraíba (AESA). Weather data were acquired from rain gauge stations located in the municipalities within the microregion of Cariri Oriental (Figure 1). Average air temperatures were estimated for the time series from January 2000 to December 2017, using the Estima_T software (Cavalcanti et al., 2006). Finally, we used data from the IBGE Automatic Recovery System (SIDRA) for upland cotton yield analysis.

The Thornthwaite monthly ETP is determined by the equation proposed by Thornthwaite (1948) for a 30-day month and 12-h photoperiod days, using the monthly mean temperature (in ${ }^{\circ} \mathrm{C}$ ) as follows (Equation 1):

$$
E T P=16 \times\left(10 \times \frac{T m}{I}\right)^{a}
$$

where:

$T m$ is the average monthly temperature;

$I$ is the annual thermal index, and

$a$ is a function of $I$.

In sequence calculated and water storage in the soil (ARM), due to the monthly water deficit in the municipality, in the months when there was no water deficit in the region, the following procedure was adopted: the positive value of monthly precipitation (PPT) subtracted the monthly evapotranspiration (ETP) was added to the storage of the previous month, obtaining storage in the referred month. This procedure was adopted while "P - ETP" was positive. However, the maximum storage value is the CAD itself, which cannot be exceeded. The value of the storage column (ARM) for months with negative P - ETP is calculated using the (Equation 2):

$$
A R M=C A D \times e^{\left(\frac{N E G}{C A D}\right)}
$$

For months with soil water storage deficit, real evapotranspiration (ETR) was estimated as in (Equation 3), but it was the same as ETP for months when soil water storage was the same as Water Capacity Available (WCA).

where:

$$
E T R=P P T+[A L T]
$$

$P P T$ is the monthly rainfall, and

$A L T$ is the modulating soil water storage.

Water deficit (WD) is calculated as the difference between ETP and ETR, and it can only occur in months with negative P - ETP. In months with excess water (EXC), the maximum storage is reached, and its value is equal to $\mathrm{P}$ ETP minus the storage change (Pereira \& Vicente, 2010).

Aridity index (Ia) expresses WD as a percentage in relation to Thornthwaite's ETP and ranges from 0 to 100 . This index was determined as in (Equation 4).

$$
I a=\frac{D E F}{E T P} \times 100
$$

Humidity index (Ih) is the relationship between water surplus (SUR) and potential ETP and expressed as a percentage (Cunha \& Martins, 2009). It was determined as in (Equation 5).

$$
I h=\frac{S U R}{E T P} \times 100
$$

After calculating Ia and Ih, we estimated moisture index $(\mathrm{Im})$, which relates the two indexes above and is responsible for determining the local climatic type (Cunha \& Martins, 2009). It was estimated according to (Equation 6).

$$
I m=\frac{(S U R-0.6 * D E F)}{E T P} \times 100
$$

Vegetation drought index (Ivd) indicates drought presence and severity during plant vegetative stages and is determined as the vegetation index, considering only the points (months) corresponding to crop vegetative stages. These points may fit in subhumid, dry, or arid sectors, i.e., characterize the studied crop.

\section{Moran's Index I (I)}

Moran's Index I $(I)$ is a statistical mechanism for verifying the spatial dependence of a given variable. This index is one of the most used and is estimated as in (Equation 7) (Almeida et al., 2008):

$$
I=\frac{\sum_{i=1}^{n} \sum_{j=1}^{n} w_{i j}\left(y_{i}-\bar{y}\right)\left(y_{j}-\bar{y}\right)}{\sum_{i=1}^{n}\left(y_{i}-\bar{y}\right)^{2}}
$$

where:

$n$ is the number of observations;

$w_{i j}$ is the element in the neighborhood matrix for the pair $i$ and $j$;

$W$ is the sum of the weights of the matrix;

$y_{i}$ and $y_{j}$ are mean deviations, and

$\bar{y}$ is the mean

This index measures the spatial autocorrelation from the product of deviations in relation to the mean, that is, Moran's Index I is a global measure of spatial autocorrelation, as it indicates the degree of spatial association present in a data set. This index varies within a range (-1 to 1$)$ : if there is spatial independence its value is zero (0); positive values (between 0 and +1 ) indicate direct correlation, that is, perfect association with spatial dependence; and negative values (between 0 and -1) indicate inverse correlation, that is, it refers to perfect dispersion. 


\section{Spatial Regression Models}

\section{Classical Regression (CR)}

A regression model (Equation 8) is based on the interest in evaluating the relation of a variable $(\mathrm{Y})$ in relation to independent variables or covariates $(\mathrm{X})$, that is, the relation between two or more variables so that one of them can be explained or have its value predicted through other variables (Bivand \& Piras, 2015). In the case of spatial data, if there is spatial autocorrelation, the generated model should incorporate the spatial structure, since the dependence between observations affects the capacity of the model for explanation (Bivand \& Piras, 2015).

$$
Y_{i}=\beta_{0}+\beta_{1} X_{1}+\beta_{2} X_{2}+\ldots+\beta_{n} X_{n}+\varepsilon_{i}
$$

where:

$Y_{i}$ is an observation of the dependent variable;

$X_{1}, X_{2} \ldots, X n$ are the independent variables;

$\beta=\left(\beta_{0}, \beta_{1}, \beta_{2} \ldots, \beta_{\mathrm{n}}\right)$ are termed as corresponding regression coefficients, and

$\varepsilon_{i}$ is the error associated with the observations of the dependent variable.

The assumption that observations are independent simplifies the model, but in the context of area data, such simplification is unlikely to happen because of the possibility of spatial dependence between the terms of the error. An alternative is to use a mixed spatial autoregressive model (Spatial Lag Model), which assigns to the response variable $y_{i}$ the spatial autocorrelation ignored. Another alternative is to apply a spatial error model, which considers spatial effects as a noise, that is, as a factor to be removed (Bivand \& Piras, 2015).

\section{Spatial autoregressive model (SARM)}

The spatial autoregressive model allows observations of the dependent variable $y_{i}$ in the area $i(i=$ $1 \ldots, n)$ to depend on observations in neighboring areas with $j \neq i$ (Bivand \& Piras, 2015), assuming the following form (Equation 9):

$$
Y_{i}=\rho \sum_{j=1}^{n} W_{i j} y_{i}+\sum_{q=1}^{Q} X_{i q} \beta_{q}+\varepsilon_{i}
$$

where:

$\varepsilon_{i}$ is the error,

$W_{i j}$ is the $(i, j)$-th element of the spatial matrix with order $n$ (that is, $n$ by $n$ ). The scalar $\rho$ is a parameter (to be estimated) that will determine the intensity of the autoregressive spatial relation between $y_{i}$ and $\sum_{j}$ $W_{i j} y_{j}$, and this parameter has as interpretation the average effect of the dependent variable relative to the spatial neighborhood in the region in question. The vector $W y$ is known as spatial lag, the matrix $X$ contains the observations of the independent variables, and the vector $\beta$ has coefficients for the independent variables.

\section{Spatial error model (SEM)}

In a spatial error model, spatial dependence is obtained through an error process, in which the errors of different areas may present spatial covariance (Bivand \& Piras, 2015). It was determined as in (Equation 10):

$$
\varepsilon_{i}=\rho \sum_{j=1}^{n} W_{i j} \varepsilon_{j}+u_{i},
$$

where:

$\rho$ is the autoregressive parameter that indicates the intensity of spatial autocorrelation between the residuals of the observed equation and measures the average effect of errors in the neighbor points relation to the residual of the region evaluated, and

$u_{i}$ is the random error term assumed to be i.i.d. Thus, spatial autocorrelation in SEMs appears in the error terms.

In matrix notation, it can be written as in (Equation 11):

$$
\varepsilon=\lambda \boldsymbol{W} \varepsilon+\boldsymbol{u}
$$

Assuming $|\lambda|<1$ leads to the following expression (Equation 12):

$$
\varepsilon=(\boldsymbol{I}-\lambda \boldsymbol{W})^{-1} \boldsymbol{u}
$$

Inserting the above expression into the classical regression model generates the following SEM (Equation 13):

$$
\boldsymbol{y}=\boldsymbol{X} \boldsymbol{\beta}+(\boldsymbol{I}-\lambda \boldsymbol{W})^{-1} \boldsymbol{u}
$$

With $E\left[u u^{\prime}\right]=\sigma^{2} I$, and the matrix of variances and covariances is defined as follows (Equation 14):

$$
E\left[\varepsilon \varepsilon^{\prime}\right]=\sigma^{2}(\boldsymbol{I}-\lambda \boldsymbol{W})^{-1}\left(\boldsymbol{I}-\lambda \boldsymbol{W}^{\prime}\right)^{-1}
$$

SEM is characterized as a combination between a classical regression model and a spatial autoregressive model in the terms of $\varepsilon$ error. Therefore, the expected value is equal to that of a classical regression model.

\section{Model selection}

According to Dobson \& Barnett (2011), the fitting algorithm must be applied not only to one model but to several that are relevant to the nature of the observations to be analyzed. If potential alternative models are disregarded, the ones best suited to the data may not be obtained. As in usual regression models, a sub-model for which the quantity below is minimal must be found by the Akaike criterion (Equation 15):

$$
A I C=D(y ; \hat{\mu})+2 p,
$$

where:

$D(y ; \hat{\mu})$ is the distance between the logarithm of the likelihood function of the saturated model ( $q$ parameters) and of the model under investigation ( $p$ parameters) evaluated in the estimation of maximum likelihood $\hat{\beta}$. A small deviation function indicates that the fit of the model with fewer parameters is as good as that of the saturated model. 


\section{RESULTS AND DISCUSSION}

Figure 2 shows the spatial distribution of accumulated crop yield of upland cotton in the microregion of Cariri Oriental over 17 years. The municipalities with the highest yields were Gurjão (maximum of 48 tons per year) and Santo André (maximum of 40 tons per year). On the other hand, the lowest yields were found in Caraúbas and Barra de São Miguel. These lowest cotton yields may have been due to several factors such as unfavorable climatic conditions, soil depletion, improper crop management, among others.
Some studies (Sena et al., 2012; Alves et al., 2015) have reported that the rainy season in the Cariri Oriental is concentrated in the months of March, April, and May, while the dry season lasts from September to November. Sena et al. (2012) pointed out that the few rains during these months must ensure that the annual rainfall does not exceed $1.5 \%$. The authors also warned that such a climate instability poses risks to rainfed farming. In this region, numerous crops are often grown but little is harvested, with even higher economic losses in El Niño years.

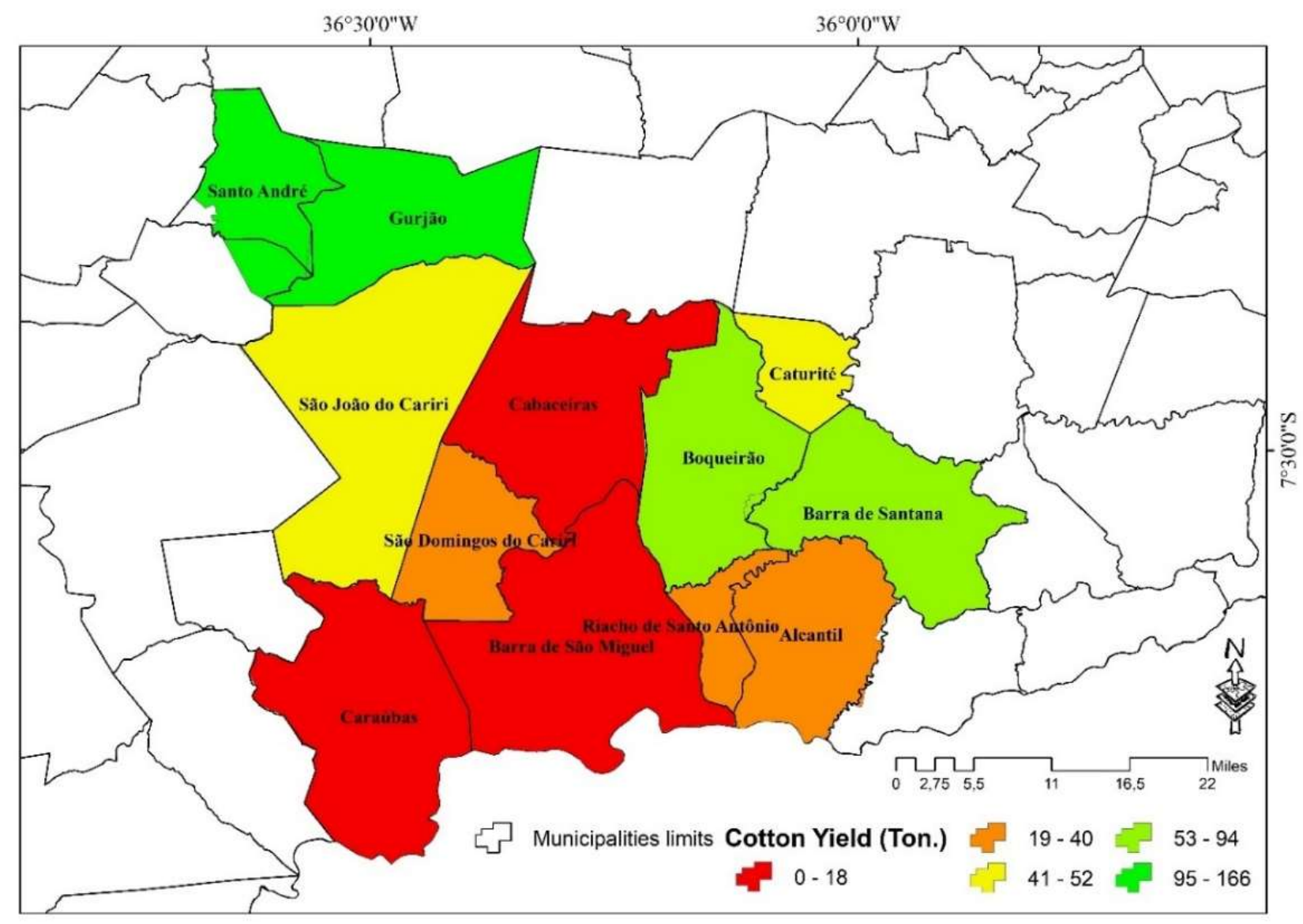

FIGURE 2. Accumulated cotton yield (in tons) between 2000 and 2017 in the microregion of Cariri Oriental, Paraíba state, Brazil.

Once the spatial distribution of upland cotton accumulated yield in the microregion of Cariri Oriental was known, Moran's index was used to estimate autocorrelations between municipalities within the area. Figure 3 shows the Moran's Scatter plot for standardized cotton yield per municipality (horizontal axis) and cotton yield in the entire microregion (vertical axis). By analyzing global spatial autocorrelation, the Moran's index remained with positive autocorrelation, which may be associated with yield concentrated within a single area (few producing municipalities). The municipalities of Gurjão and Santo André showed high cotton yields and are surrounded by other municipalities with high yields. The opposite occurred for municipalities with low cotton yields. Based on this autocorrelation degree, we can infer that the municipalities of High-High $(\mathrm{HH})$ typologies $\left(1^{\text {st }}\right.$ quadrant) have great relevance in fiber production if compared to the other municipalities. 


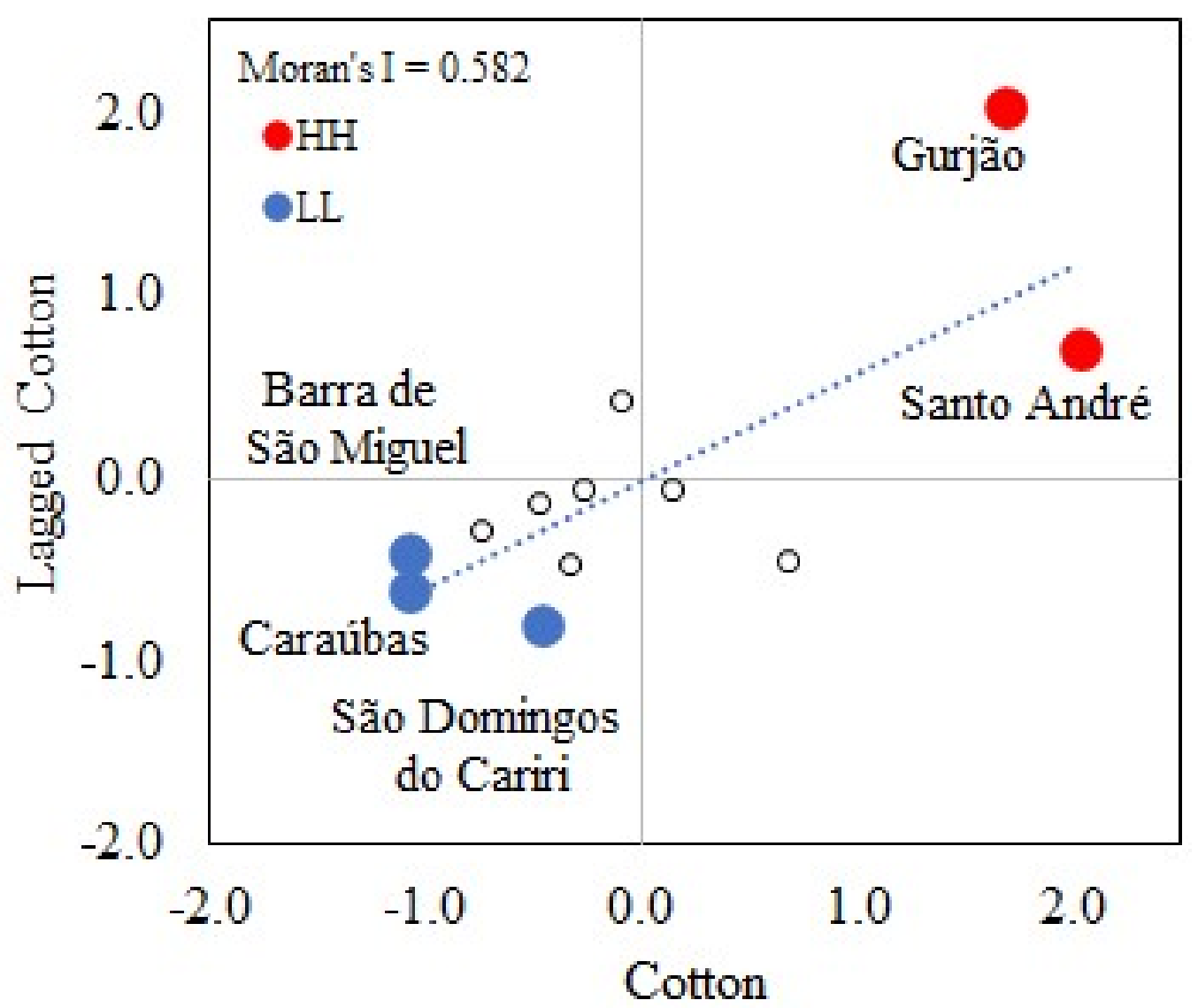

FIGURE 3. Moran's Index I scatter plot for cotton yield in the microregion of Cariri Oriental, Paraíba state, Brazil.

Spatial clusters must be delineated for edaphoclimatic risk zoning in semiarid regions. As highlighted in other studies, these spatial analyses are crucial due to their potential applications for environmental health (Wang \& Hu, 2012), heat risk (Ho et al., 2015), water balance (Liu et al., 2016), and power generation (Tyralis et al., 2017).

Geospatial analysis techniques help detect cotton cultivation weaknesses and define more favorable areas with greater adaptive capacity. By analyzing the prediction of independent variables (Table 1), we found that mean temperature (T_Mean) and moisture index (Im) had negative contributions (i.e., cotton yield decreased as they increased). This result may be related to temperature and moisture influences on cotton phenological stages, as highlighted by Silva et al. (2012).

TABLE 1. Regression models fitted to cotton yield data as a function of climatic variables in the microregion of Cari Oriental, Paraíba state, Brazil.

\begin{tabular}{|c|c|c|c|}
\hline Covariate & $\mathrm{CR}$ & SARM & SEM \\
\hline Intercept & 1279.89 & 1288.81 & 1563.81 \\
\hline Ivd & 65.1366 & 56.0455 & 64.1285 \\
\hline Ia & 352.633 & 373.536 & 384.292 \\
\hline $\operatorname{Im}$ & -561.02 & -608.96 & -611.279 \\
\hline Ih & 574.283 & 612.334 & 627.637 \\
\hline T_Mean & -82.7993 & -74.1927 & -92.7132 \\
\hline $\mathrm{R}^{2}$ & 0.918737 & 0.924157 & 0.949506 \\
\hline AIC & 110.276 & 111.586 & 107.194 \\
\hline$\rho$ & - & 0.188864 & -0.811411 \\
\hline
\end{tabular}

Ivd (Vegetation drought index); Ia (Aridity index); Im (Moisture index); Ih (Humidity index); T_Mean (Mean air temperature $\left({ }^{\circ} \mathrm{C}\right)$.

Canopy temperature is a strong indication of water stress, because when stomatal conductivity decreases, temperature increases, thus indicating stress. According to Munitz et al. (2017) and Netzer et al. (2019), prolonged water stress can negatively affect crop production. These authors emphasized that, during cotton growth and emergence, these water relations are even more relevant since emergence speed depends mainly on temperature $\left(\sim 32^{\circ} \mathrm{C}\right)$. Moreover, soil moisture is essential for germination, beginning of seedling development, and between the formation of the first flower buds and beginning of fruit opening (35 to 120 days).

Table 1 shows the results of the spatial regression models. The SEM results improved significantly and 
explained $95 \%$ of the variability in the influence of climatic variables on cotton yield according to AIC value, that is, a strong to very strong correlation. For Azevedo \& Silva (2007), the ideal mean air temperature range for satisfactory cotton yields is between 20 and $30{ }^{\circ} \mathrm{C}$. Bibi et al. (2008) reported that cotton plants are expected to have a high photosynthetic rate at $32{ }^{\circ} \mathrm{C}$, but net photosynthetic rate starts to decrease from $22{ }^{\circ} \mathrm{C}$. Also in this context, Silva et al. (2012) claimed that temperature is also important for a proper reproductive development (flowering and shoot formation). The other variables had positive coefficients, hence the opposite of mean temperature and the Im. Thus, cotton yield is higher as variables have higher values.

Our results (Table 1) confirmed that including spatial dependence indicators among variables improves the predictive power of a model and rules out spatial autocorrelation. In other words, such inclusion allows generating randomly distributed residues within the study area. The superiority of alternative models (SARM and
SEM) over the traditional (CR) can be seen in Figure 4 (A$\mathrm{C})$. This figure shows the residual spatial distribution and predictive capacity of each model. The SEM (Figure 4C) had a larger number of municipalities with negative residues. This model, therefore, tends to underestimate cotton yields in the micro-region of Cariri Oriental between 2000 and 2017.

Residual variability (Figure 4D) was determined as the difference between the observed and model-estimated data. For this variability, the SEM had the best fit, showing a distribution pattern close to normal. For all models (CR, SARM, and SEM), cotton yields were overestimated within the transition areas between the most productive municipalities. However, overestimates and underestimates are relatively low when considering the interquartile difference. This may be directly associated with rainfall distribution and regularity, and thermal amplitude in each municipality.
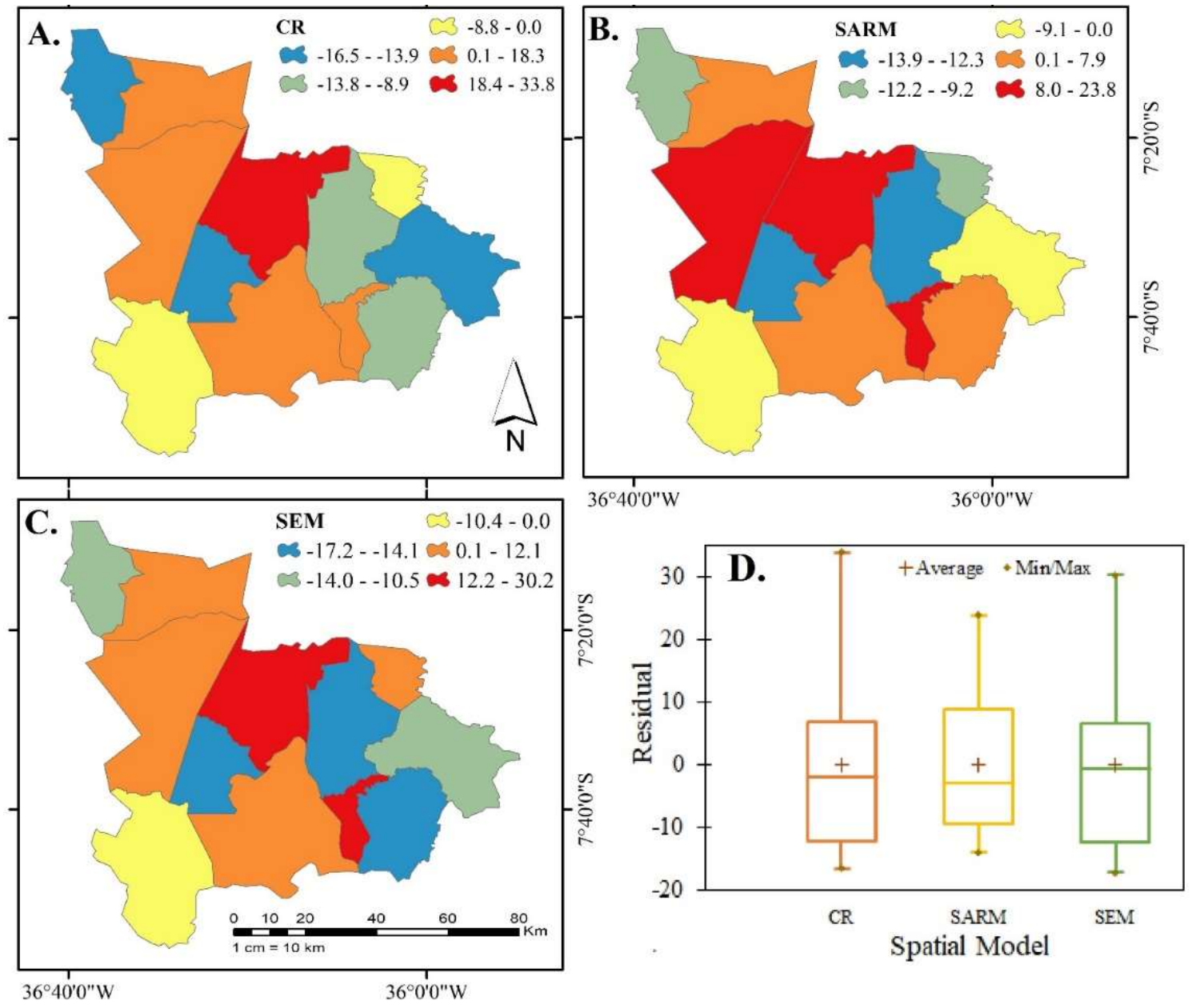

FIGURE 4. Maps of residuals from the classical regression - CR (A), spatial autoregressive model - SARM (B), and spatial error model - SEM (C), and of the variability of residuals (D) for cotton yield in the microregion of Cariri Oriental, Paraíba state, Brazil.

Quantitative and qualitative aspects of upland cotton yield are influenced by climate, which is composed of several parameters such as rainfall, temperature, humidity, wind speed, and light intensity. Therefore, knowing the study area comprehensively allows us to identify which are the climatic conditions most favorable for cotton planting, as unfavorable conditions can result in significant yield losses. In this context, Costa et al. (2020) carried out a study in northeastern Brazil and observed that the spatial patterns of accumulated degrees show reductions, but with a positive trend for extreme events within a short period.

Given the climate change scenario, Silva et al. (2012) analyzed upland cotton cultivation in rainfed conditions in northeastern Brazil and found that, for $1.5^{\circ} \mathrm{C}$ increments in mean air temperature, the availability of areas favorable to cotton cultivation is directly related to increased water supply from rainfall. According to Rocha Júnior et al. (2020), Northeastern Brazil presents climate 
vulnerability as it is the most populous dry region worldwide, with accentuated climate variability; therefore, the local population is exposed to the risk of droughts with strong environmental and social impacts. In this sense, drought studies using advanced research methods, especially in the climate change context, is critical to improving crisis management in long dry spells.

Overall, climate-related factors are commonly used to determine irrigation water amounts both in time and space (Masseroni et al., 2016; Haghverdi et al., 2019). Moreover, the spatial variability of effects from multiple climatic variables on crop yields may be modeled to predict the yield spatial variability itself. Therefore, crop planting should be carried out after significant climate studies and analyses, combined with knowledge on soils, so that positive interventions could be made in crops in the most favorable periods for each region (Echer et al., 2010).

\section{CONCLUSIONS}

The spatial autocorrelation of cotton yield and agrometeorological elements can be verified through an exploratory analysis of spatial variability in the areas, using statistical techniques such as Moran's I index.

Two spatial regression models (MEAR and MEE) with global effects can be applied to incorporate the observed spatial dependence, showing a moderate to very strong correlation intensity. These regression models have better results than the classic model. Therefore, the inclusion of spatial dependence in these models improves cotton yield estimates for the microregion of Cariri Oriental, Paraíba state, Brazil.

\section{ACKNOWLEDGMENTS}

This study was conducted as part of the Master's thesis of the second author, who would like to thank the National Council for Scientific and Technological Development (CNPQ) for granted scholarship, under process $\mathrm{n}^{\circ} 140740 / 2018-0$, and the Academic Unit of Atmospheric Sciences (UACA) of the Federal University of Campina Grande (UFCG) in Brazil for funding and support during the study. We are all very grateful to the anonymous reviewers and editors for their comments and considerations, which helped to improve the research.

\section{REFERENCES}

ABRAPA - Associação Brasileira dos Produtores de Algodão (2018) Algodão no Brasil. Available: https:/www.abrapa.com.br/Paginas/dados/algodao-nobrasil.aspx. Accessed: Maio 19, 2020

Almeida ES, Perobelli FS, Ferreira PGC (2008) Existe convergência espacial da produtividade agrícola no Brasil. Revista Economia e Sociologia Rural 46(1): 1806-9479. DOI: https://doi.org/10.1590/S0103-20032008000100002

Alvares CA, Stape JL, Sentelhas PC, Gonçalves JL de M, Sparovek G (2014) Köppen's climate classification map for Brazil. Meteorologische Zeitschrift 22 (6): 711-728. DOI: https://doi.org/10.1127/0941-2948/2013/0507
Alves TLB, Azevedo PV, Farias AA (2015)

Comportamento da precipitação pluvial e sua relação com o relevo nas microrregiões do Cariri Oriental e Ocidental do estado da Paraíba. Revista Brasileira de Geografia Física 08 (6): 1984-2295.

DOI: https://doi.org/10.26848/rbgf.v8.6.p1601-1614

Ahmadi M, Baaghide M, Roudbari AD, Asadi M (2018)

Modeling the role of topography on the potential of tourism climate in Iran. Modeling Earth Systems and Environment 4 (1): 13-25.

Andrade AS, Silva MT, Serrão EAO, Silva VPR, Cavalcanti EP, Souza EP, Braga CC (2021) Exploring spatial dependence of cowpea-beans yield using global and local autocorrelation statistics in the Eastern Cariri region of Paraíba. Ciência Rural 51(12): e20200666. DOI: https://doi.org/10.1590/0103-8478cr20200666

Azevedo PV de, Silva FD dos S (2007) Risco climático para o cultivo do algodoeiro na região Nordeste do Brasil. Revista Brasileira de Meteorologia 22: 408-416.

Bibi CA, Oosterhuis DM, Gonias ED (2008) Fotossíntese, rendimento quântico do fotossistema II e vazamento de membranas afetadas por altas temperaturas nos genótipos de algodão. Revista de Ciência do Algodão 12: 150-159.

Bivand R, Piras G (2015) Comparing Implementations of Estimation Methods for Spatial Econometrics. Journal of Statistical Software 63 (18): 1548-7660. DOI: https://doi.org/10.18637/jss.v063.i18

Cavalcanti EP, Silva V de PR, Sousa F de AS (2006) Programa computacional para a estimativa da temperatura do ar para a região Nordeste do Brasil. Revista Brasileira de Engenharia Agrícola e Ambiental 10 (1): 140-147. DOI: https://doi.org/10.1590/S1415-43662006000100021.

Costa RL, Baptista GMM, Gomes HB, Silva FDS, da Rocha Júnior RL, Salvador MA, Herdies DL. (2020) Analysis of climate extremes indices over northeast Brazil from 1961 to 2014. Weather Clim Extremes 28: 100254. https://doi.org/10.1016/j.wace.2020.100254.

Cunha AR, Martins D (2009) Classificação climática para os municípios de Botucatu e São Manuel, SP. Irriga 14 (1): 1808-8546. DOI: https://doi.org/10.15809/irriga.2009v14n1p1-11

Da Rocha Júnior RL, Dos Santos Silva FD, Costa RL, Gomes HB, Herdies DL, Da Silva VPR, Xavier AC (2019) Analysis of the Space-Temporal Trends of Wet Conditions in the Different Rainy Seasons of Brazilian Northeast by Quantile Regression and Bootstrap Test. Geosciences 9 (11): 457. DOI: https://doi.org/10.3390/geosciences9110457

Da Rocha Júnior RL, Dos Santos Silva FD, Costa RL, Gomes HB, Pinto DDC, Herdies DL (2020). Bivariate assessment of drought return periods and frequency in brazilian northeast using joint distribution by copula method. Geosciences 10 (4):

https://doi.org/10.3390/geosciences10040135 
Di Leo N, Escobedo FJ, Dubbeling M (2016) The role of urban green infrastructure in mitigating land surface temperature in Bobo-Dioulasso, Burkina

Faso. Environment, Development and Sustainability 18(2): 373-392.

Dobson AJ, Barnett AG (2011) An introduction to generalized linear models. Statistical Papers 53: 805-806.

Echer FR, Custódio CC, Hossomi ST, Dominato JC, Machado Neto NB (2010) Estresse hídrico induzido por manitol em cultivares de algodão. Revista Ciência Agronômica 41 (4): 638-645.

Foley JA, Ramankutty N, Brauman KA, Cassidy ES, Gerber JS, Johnston M, Mueller ND, O’Connell C, Ray DK, West PC, Balzer C, Bennett EM, Carpenter SR, Hill J, Monfreda C, Polasky S, Rockström J, Sheehan J, Siebert S, Tilman D, David Zaks PM (2011) Solutions for a cultivated planet. Nature 478: 337- 342.

Fotheringham AS, Crespo R, Yao J (2015) Geographical and temporal weighted regression (GTWR). Geographic Analytics 47 (4):431-452. DOI:

https://doi.org/10.1111/gean.12071

Gilio TAS, Araújo DV, Krause W, Rosa HHR, Ascari JP (2017) Genetic divergence among cotton genotypes grown in the main season and off season. Revista Caatinga 30 (2): 377-390.

Goldstein L, Fink A, Meitin S, Bohadana O, Lutenberg G (2018) Ravid Applying machine learning on sensor data for irrigation recommendations: revealing the agronomist's tacit knowledge. Precision Agriculture 19 (3): 421-444. DOI: https://doi.org/10.1007/s11119-017-9527-4

Haghverdi A, Leib B, Washington-Allen R, Wright W, Ghodsi S, Grant T, Vanchiasong P (2019). Studying crop yield response to supplemental irrigation and the spatial heterogeneity of soil physical attributes in a humid region. Agriculture 9 (2): 43. DOI:

https://doi.org/10.3390/agriculture9020043

Ho H, Knudby A, Huang W (2015) A spatial framework tomap heat health risks at multiple scales. International Journal Environmental Research and Public Health 12: 15046. DOI: https://doi.org/10.3390/ijerph121215046

IBGE - Instituto Brasileiro de Geografia e Estatística (2015). Available:

http://cidades.ibge.gov.br/xtras/perfil.php?lang=\&codmun $=250053$. Accessed: June 1, 2019.

IPCC (2013) Summary for policymakers. In: Stocker TF, Qin D, Plattner GK, Tignor M (eds). Climate change 2013: The physical science basis. Contribution of Working Group I to the Fifth Assessment Report of the Intergovernmental Panel on Climate Change. Cambridge University Press, p 3-29.

Liu C, Liu J, Hu Y, Wang H, Zheng C (2016) Airborne thermal remote sensing for estimation of groundwater discharge to a river. Groundwater 54: 363-373. DOI: https://doi.org/10.1111/gwat.12362
Lobell DB, Burke MB (2010) On the Use of Statistical Models to Predict Crop Yield Responses to Climate Change. Agricultural and Forest Meteorology 150: 1443-1452

Luo X, Peng Y (2016) Scale effects of the relationships between urban heat Islands and impact factors based on a geographicallyweighted regression model. Remote Sensing 8(9): 760.

Masseroni D, Facchi A, Gandolfi C (2016) Is soil water potential a reliable variable for irrigation scheduling in the case of peach orchards? Soil Science 181 (6): 232-240. DOI: https://doi.org/10.1097/SS.0000000000000151

Masseroni D, Ortuani B, Corti M, Gallina PM, Cocetta G, Ferrante A, Facchi A (2017) Assessing the reliability of thermal and optical imaging techniques for detecting crop water status under different nitrogen levels.

Sustainability 9 (9): 1548.

DOI: https://doi.org/10.3390/su9091548

Munitz, S., Netzer, Y., Schwartz, A., 2017. Sustained and regulated deficit irrigation of field-grown Merlot grapevines. Australian Journal of Grape and Wine Research 23 (1): 87-94. DOI:

https://doi.org/10.1111/ajgw.12241

Nascimento SS, Alves JJA (2008) Ecoclimatologia do Cariri Paraibano. Revista Geográfica Acadêmica 2 (3): 1678-7226.

Netzer Y, Munitz S, Shtein I, Schwartz A (2019) Structural memory in grapevines: early season water availability affects late season drought stress severity. European Journal of Agronomy 105: 96-103. DOI: https://doi.org/10.1016/j.eja.2019.02.008

Peeters A, Zude M, Käthner J, Ünlü M, Kanber R, Hetzroni A (2015) Ben-Gal Getis-Ord's hot- and coldspot statistics as a basis for multivariate spatial clustering of orchard tree data. Computers and Electronics in Agriculture 111: 140-150. DOI:

https://doi.org/10.1016/j.compag.2014.12.011

Pereira RN, Vicente AA (2010) Environmental impact of novel thermal and non-thermal technologies in food processing. Food Research International 43 (7): 1936-194.

Sena JPO, Melo JS, Lucena, DB, Melo ECS (2012)

Comparação entre dados de chuva derivados do Climate Prediction Center e observados para a região do Cariri Paraibano. Revista Brasileira de Geografia Física 2: 412-420.

Scudiero E, Teatini P, Corwin DL, Deiana R, Berti A, Morari F (2013) Delineation of site-specific management units in a saline region at the Venice Lagoon margin, Italy, using soil reflectance and apparent electrical conductivity. Computers and Electronics in Agriculture 99: 54-64. DOI: https://doi.org/10.1016/J.COMPAG.2013.08.023

Silva FDS, Costa RL, Rocha Júnior RL, Gomes HB, Azevedo PV, Silva VPR, Monteiro LA (2020a). Cenários Climáticos e Produtividade do Algodão no Nordeste do Brasil. Parte I: Calibração e Validação do Modelo Agrometeorológico. Revista Brasileira de Meteorologia 35(spe): 903-912. DOI: https://dx.doi.org/10.1590/010277863550087 
Silva FDS, Costa RL, Rocha Júnior RL, Gomes HB, Azevedo PV, Silva VPR, Monteiro LA (2020b) Cenários Climáticos e Produtividade do Algodão no Nordeste do Brasil. Parte II: Simulação Para 2020 a 2080. Revista Brasileira de Meteorologia 35(spe): 913-929. DOI: https://dx.doi.org/10.1590/0102-77863550102

Silva, MT, Margalho ES, Serrão EAO, Souza AC, Soares CS, Santos CAC, Silva BB (2021) Application of Spatial Modeling of Biophysical Variables in an Urbanized Area in the Amazon: The Case of the Metropolitan Area of Belém-Pará. Revista Brasileira de Meteorologia 36(2): 271-283. DOI: https://doi.org/10.1590/0102-77863620063

Silva MT, Silva VPR, Azevedo PV (2012) O cultivo do algodão herbáceo no sistema de sequeiro no Nordeste do Brasil, no cenário de mudanças climática. Revista Brasileira de Engenharia Agrícola e Ambiental 16 (1): 1415-4366. DOI: https://doi.org/10.1590/S141543662012000100011
Thornthwaite CW (1948) An approach towards a rational classification of climate. Geographical Review 38: 55-94. DOI: https://doi.org/10.2307 / 210739

Tyralis H, Mamassis N, Photis YN (2017) Spatial analysis of the electrical energy demand in Greece. Energy Policy 102: 340-352. DOI: https://doi.org/10.1016/j.enpol.2016.12.033

Wang JF, Hu Y (2012) Environmental health risk detection with GeogDetector. Environmental Modeling Software 33: 114-115. DOI: https://doi.org/10.1016/j.envsoft.2012.01.015

Wolfert S, Ge L, Verdouw C, Bogaardt MJ (2017) Big data in smart farming - a review. Agricultural Systems 153: 6980. DOI: https://doi.org/10.1016/J.AGSY.2017.01.023

Zhao H, Ren Z, Tan J (2018) The spatial patterns of land surface temperature and its impact factors: spatial nonstationarity and scale effects based on a geographicallyweighted regression model. Sustainability 10: 2242. DOI: https://doi.org/10.3390/su10072242 